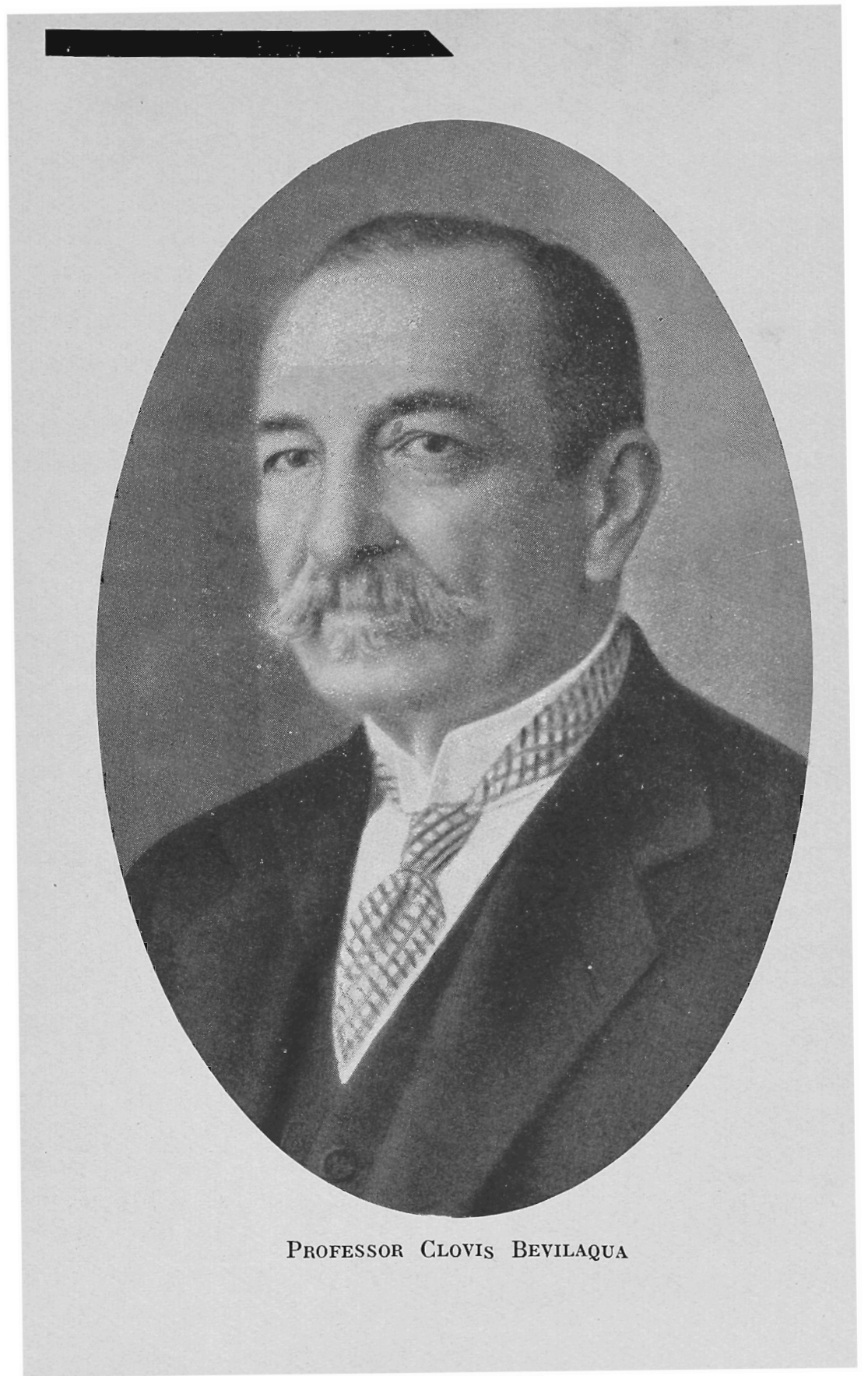




\section{Clovis Bevilaqua}

Viçosa (Ceará) 1859

Rio de Janeiro 1944.

Ao saber da sua morte, os que só o conheciam pelas obras não puderam lembrar-lhe a feição humana e sábia, senão através do muito que escrevera, nas letras, na economia, na história, no direito, na sociologia, na filosofia. Só por elas viram como, nele, a erudição fez-se cultura, o adorno verbal fez-se simplicidade, a ciencia mudou-se em sabedoria, o particular universalizou-se.

Mas os que o conheceram de perto recordaram tambem o homem generoso, que tantas vezes interrompera 0 livro, para ensinar e animar, tão simples e acolhedor, que nada parecia dar, senão receber.

E pela grandeza daquela vida compreenderam como ele realizára o sentido da vida universal, em que a arvore, cuja sombra abriga, côa o sól para aquecer; onde a chuva triste sóbe, em seiva, à flor e ao fruto; onde as azas que batem, tambem buscam pouso. $\mathrm{E}$ em que o suor goteja e produz serenidade.

A Faculdade de Direito, que conferiu a sua mais alta dignidade ao autor do projeto do Codigo Civil, curva-se em contrita homenagem ante os ensinamentos de sabedoria e humildade daquela grande vida ora extinta. 